Volume 3, Issue 1, pages 125-130

p-ISSN 2655-8564, e-ISSN 2685-9432

\title{
Conceptual Design of Modular Chassis Jig of Student Competition Car
}

\author{
Heryoga Winarbawa ${ }^{1, *}$ \\ ${ }^{1}$ Department of Mechanical Engineering, Faculty of Science \\ and Technology, Sanata Dharma University, Yogyakarta, Indonesia \\ *Corresponding Author: winarbawa@gmail.com \\ (Received 28-05-2021; Revised 16-06-2021; Accepted 16-06-2021)
}

\begin{abstract}
Chassis jig is needed to ensure that the welded chassis components does not warp or deform during welding process. Through concept screening and concept scoring, multiple design of chassis jigs is narrowed down to next development process. This study aims to design a chassis jig for the fabrication of student car competition chassis. The desired result of this design process is chassis jig with the ability to manufacture a wide variety of student competition car chassis.
\end{abstract}

Keywords: Car, chassis, jig, fixture

\section{Introduction}

Students of mechanical engineering programs are often challenged to study implementations. Student competition is one of study implementations. Those competitions drive students to build something based on what they learn in class. Formula Student (FS), Shell Eco Marathon (SEM), Kompetisi Mobil Hemat Energi (KMHE), and Kompetisi Mobil Listrik Indonesia (KMLI) are examples where student need to build cars to compete. 


\section{International Journal of Applied Sciences and Smart Technologies}

Volume 3, Issue 1, pages 125-130

p-ISSN 2655-8564, e-ISSN 2685-9432

Car chassis is the important thing to ensure vehicle stability and driver/passenger safety. There are several types of chassis, ladder frame, space frame, and monocoque. A lot of student teams apply space frame chassis for their cars. Space frame chassis is chosen due to simpler manufacturability and cost effectiveness.

Space frame chassis are manufactured by welding some of tubing. To ensure accuracy, space frame chassis materials are welded on chassis jig and several fixtures. Welding fixtures are typically the most common devices used to align and retain the various pieces for welding [1]. Some chassis jig on the market are using steel as their table top. Steel table top are usually coated with other material to prevent rust.

The scope of this study was limited to accommodate competition car chassis welding process. This study summarizes the design of chassis jig that accommodate several kind of chassis that suite for each competition.

\section{Research Methodology}

This study applied three stages of process as shown at Figure 1. The first stage is to collect all requirement measurement, such as, length, width, and height of car chassis based on technical rules for each competition. As the second stage, we recall that concept selection is the process of evaluating concepts with respect to customer needs and other criteria, comparing the relative strengths and weaknesses of the concepts, and selecting one or more concepts for further investigation, testing, or development [2]. Material selection criteria are limited to ease of manufacturing and assembly process, and rust resistance properties. The third stage is when chassis jig was design and some feature were added.

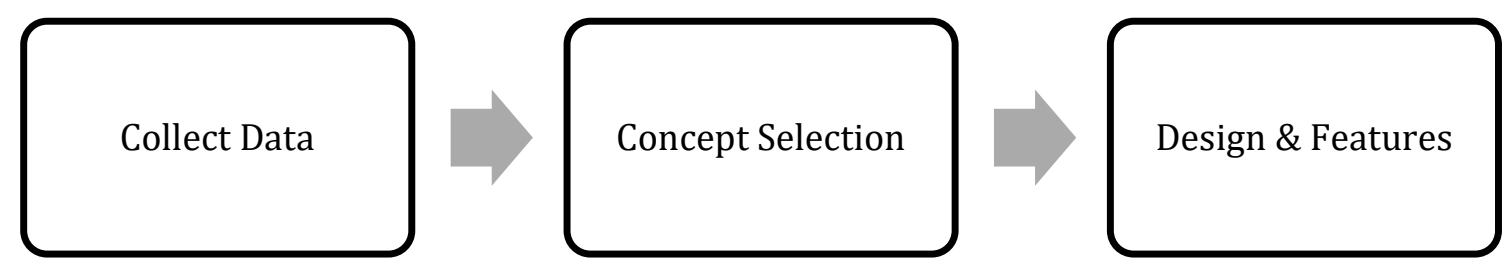

Figure 1. Study process 


\section{International Journal of Applied Sciences and Smart Technologies}

Volume 3, Issue 1, pages 125-130

p-ISSN 2655-8564, e-ISSN 2685-9432

Collect Data. Car dimension can be found at technical data of each competition [3-5]. The KMHE competition adopts SEM environment, so basically the technical rules for car dimension are the same. Maximum dimension requirement are selected so the chassis that need to be manufactured doesn't break the competition rules. The closest car chassis CAD design for each type of competition are also collected to simulate availability on chassis jig top.

Concept Selection. A chassis jig is constructed by table top and some legs. Steel tube, hollow aluminum tube, and aluminum extrusion are the most common materials to build such thing. Concept A is bulky, heavy duty chassis jig constructed by square hollow steel as frame and thick steel sheet as table top. Concept B is knock-down slatted steel sheet as top, frame and some legs. Concept $\mathrm{C}$ is constructed by all aluminum extrusion. Concept $\mathrm{D}$ has steel sheet with welded ribs as table top, and bent steel sheet that constructed as frame. Concept $\mathrm{E}$ is assembled by welded square hollow steel and aluminum extrusion as table top. All of those concepts are narrowed down through concept screening which tabulated in Table 1.

Table 1. Concept screening

\begin{tabular}{|c|c|c|c|c|c|}
\hline & \multicolumn{5}{|c|}{ Concepts } \\
\hline Selection Criteria & A & B & $\mathrm{C}$ & $\mathrm{D}$ & $\mathrm{E}$ \\
\hline Weight & - & - & 0 & + & - \\
\hline Rust Resistant & - & 0 & 0 & 0 & 0 \\
\hline Easy to Assemble & - & 0 & 0 & + & + \\
\hline Manufacturing Cost & - & - & 0 & + & + \\
\hline Fixture Modularity & + & + & 0 & 0 & 0 \\
\hline Rigidity & + & + & 0 & - & + \\
\hline Easy to Move & - & + & 0 & + & - \\
\hline Sum +’s & 2 & 3 & 0 & 4 & 3 \\
\hline Sum 0 's & 0 & 2 & 7 & 2 & 2 \\
\hline Sum -'s & 5 & 2 & 0 & 1 & 2 \\
\hline Net Score & -3 & 1 & 0 & 3 & 1 \\
\hline Rank & 5 & 3 & 4 & 1 & 2 \\
\hline & No & Yes & Combine & Yes & Combine \\
\hline
\end{tabular}

Through concept screening, concept variation has been reduced to three concepts, Concept B, Concept D, and combination of Concept C and E, thus called Concept CE. Further investigated issue needs to be clarified before chosen final concept. Selection criteria are weighted to increase the sensitivity of concept determination as shown in Table 2. 


\section{International Journal of Applied Sciences and Smart Technologies}

Volume 3, Issue 1, pages 125-130

p-ISSN 2655-8564, e-ISSN 2685-9432

Table 2. Concept scoring

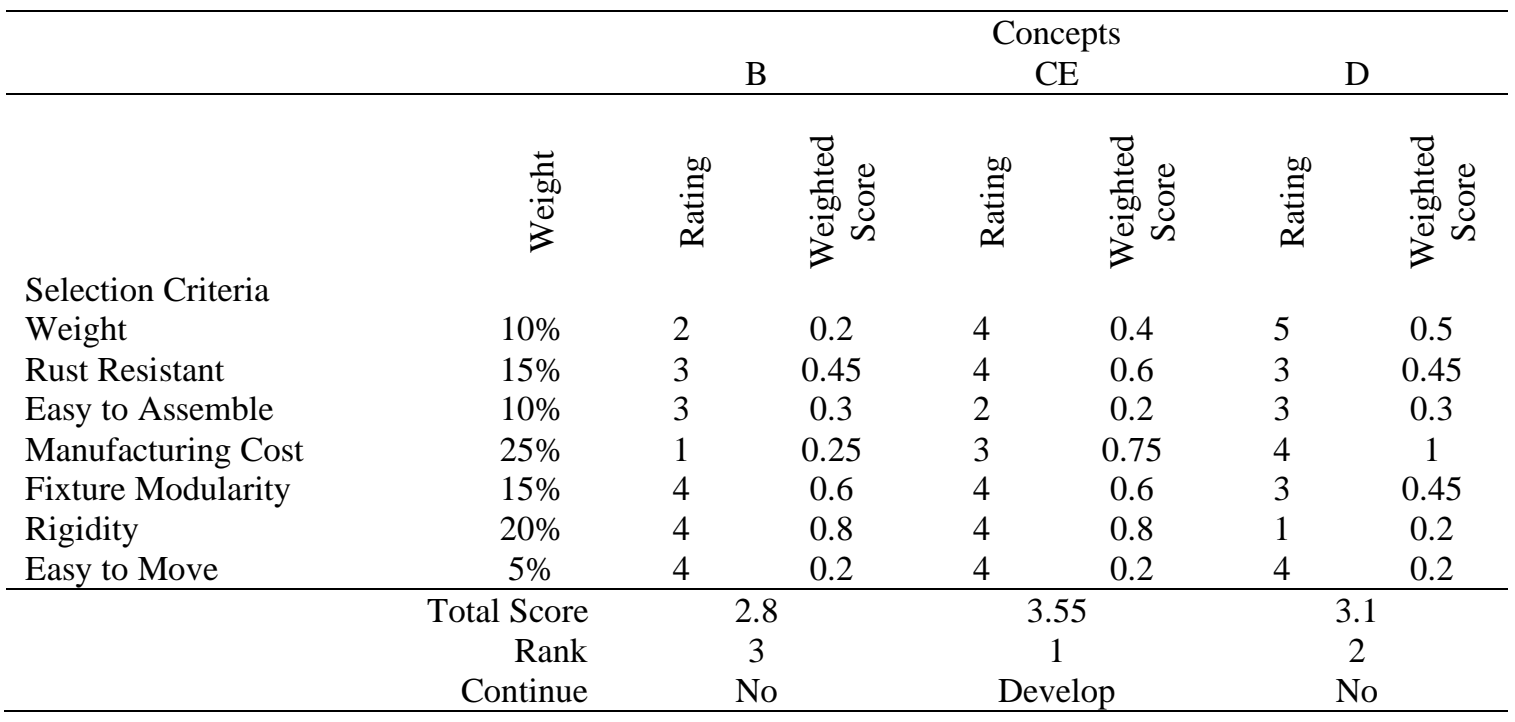

The total score for each concept is the sum of the weighted scores, and formulated as:

$$
S_{j}=\sum_{i=1}^{n} r_{i j} w_{i} .
$$

Here, $r_{i j}$ is the raw rating of concept $j$ for the $i$ th criterion, $w_{i}$ represents the weighting for $i$ th criterion, $n$ is the number of criteria, and $S_{j}$ denotes the total score of concept $j$.

\section{Results and Discussion}

Chosen concept is combination of concept $\mathrm{C}$ and $\mathrm{E}$. Concept $\mathrm{CE}$ is constructed by welded square hollow steel as bottom part of frame and slatted arrangement of aluminum extrusion as table top as shown in Figure 2a. From bottom part of frame to table top is raised by another aluminum extrusion. That configuration provide better stability as center gravity is lower. The lower part also useful for storing jigs/fixtures, welding equipment, and power tools that required during chassis fabrication. Figure $2 \mathrm{~b}$ shows chassis jig with SEM prototype car chassis on top of it. For FS car chassis, some additional jig members were added to support front and back section of car chassis as shown in Figure 2c. Fixtures for holding chassis materials will be design as future work. 


\section{International Journal of Applied Sciences and Smart Technologies}

Volume 3, Issue 1, pages 125-130

p-ISSN 2655-8564, e-ISSN 2685-9432

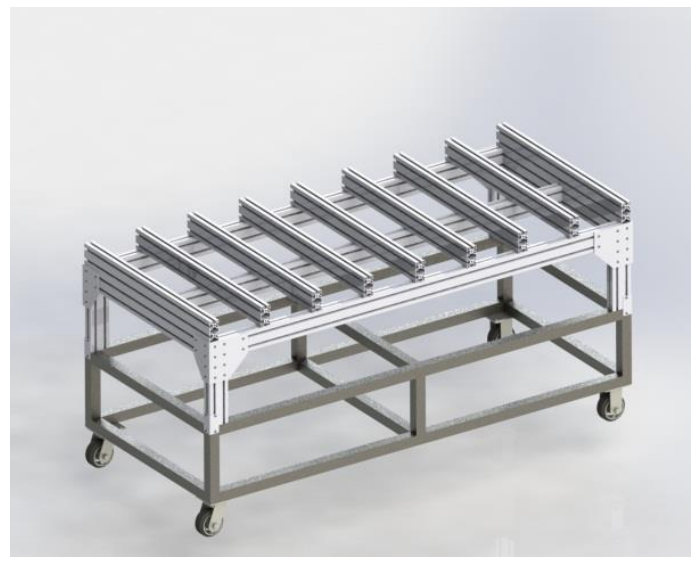

(a)

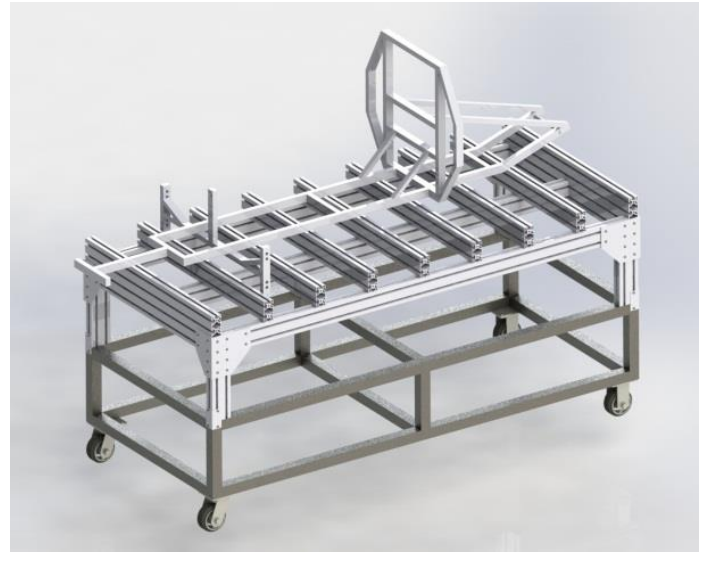

(b)

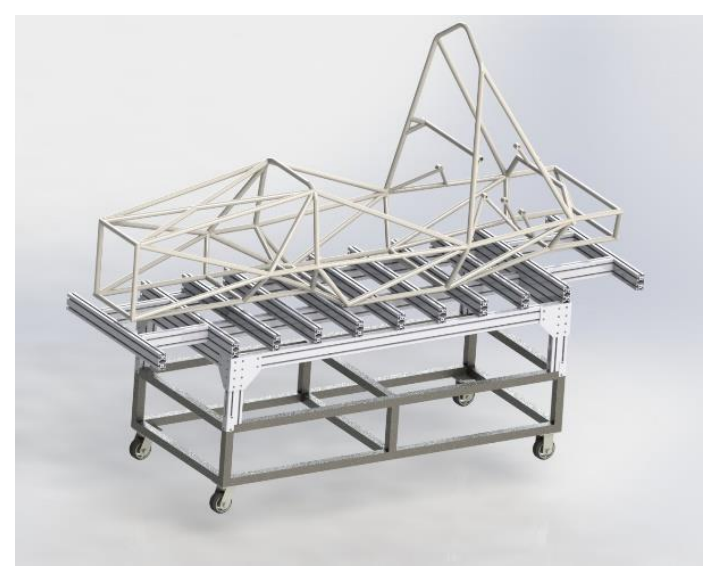

(c)

Figure 2. Some illustrations of chassis jigs: (a) Chassis jig, (b) Chassis jig with SEM prototype car chassis, (c) Chassis jig with FS car chassis

\section{Conclusion}

Concept CE has been concluded as best concept after several steps. The excellence of Concept CE amongst others are:

- Lightweight: using aluminum extrusion as the most component are reducing overall weight

- Rust resistant: aluminum is already rust resistant since it already provides oxide film all over the surface.

- Easy to assemble: aluminum extrusion provides tracks that has standardized dimensions and their own accessories such as nuts, bolts and connectors. 


\section{International Journal of Applied Sciences and Smart Technologies}

Volume 3, Issue 1, pages 125-130

p-ISSN 2655-8564, e-ISSN 2685-9432

- Low manufacturing cost: since it already has tracks and accessories, fabricating process and assembly is just simply as cut and connect. It does not need complex manufacturing process on many machines.

- Modular fixture: lower fixture design are mainly based on aluminum extrusion track design, and the top one are following work piece design, that is, aluminum hollow tube for chassis.

- Rigid enough: aluminum extrusion cross-section is already designed to maintain rigidity along its length. Bigger cross-sectional area provides minimum deflection and maximum rigidity when they are made into a structure.

- Easy to move: since it is already lightweight because half part is using aluminum material, the movement also help by castor wheel.

Note that because this concept using aluminum as top, so it does not provide impact protection. Top surface is only used as planar reference and placing fixtures.

\section{References}

[1] E. G. Hoffman, Jig and Fixture, 5th Edition, Clifton Park, NY: Delmar, 2004.

[2] K.T. Urlich and S.D Epingger, Product Design and Development, New York, NY: McGraw-Hill Education, 2016.

[3] "Formula Student," [Online]. Available: https://www.imeche.org/docs/defaultsource/1-oscar/formula-student/2021/forms/fs2020-rules.zip?sfvrsn=2. [Accessed 24 March 2021].

[4] "Shell Eco Marathon," [Online]. Available: https://base.makethefuture.shell/en_gb/service/api/home/shell-eco-marathon/globalrules/_jcr_content/root/content/document_listing/items/download_1733386233.strea m/1598973488368/0e057b48fe5e2adc044ac860f83ebf26f8ccd5f9/shell-ecomarathon-2020-official-rul. [Accessed 24 March 2021].

[5] "Kompetisi Mobil Listrik Indonesia," [Online]. Available: http://kmli.polban.ac.id/component/phocadownload/category/1-panduanlomba.html?download=6:panduan-kmli-xi-2019. [Accessed 24 March 2021]. 